удК 342.2

DOI https://doi.org/10.32837/apdp.v0i85.1825

М. І. Даніліна

\title{
КОНСТИТУЦІЙНІ ОСНОВИ СТАНОВЛЕННЯ СОЦІАЛЬНОЇ ДЕРЖАВИ
}

Постановка проблеми. Становлення України як соціальної держави викликає в сучасної вітчизняної юридичної науки низку проблем, пов'язаних з аналізом конституційно-правових засад реалізації, встановлених Основним Законом цілей і пріоритетів суспільного та державного розвитку.

У статті 1 Конституції України зазначається: «Україна є суверенна і незалежна, демократична, соціальна, правова держава» [1], що накладає певні зобов'язання на державу, зокрема зобов'язання поважати права людини, що вимагає від державних органів та інших представників держави утримуватися від порушень прав людини; зобов'язання захищати права людини, що передбачає обов'язок держави захистити носіїв прав людини від протиправного втручання третіх осіб в їх реалізацію і покарати правопорушників; зобов'язання забезпечувати здійснення прав людини, що вимагає від держави здійснювати активні дії з метою сприяння повній реалізації прав людини, досягнення їх результату.

Конституція України закріпила принцип відповідальності держави перед людиною за свою діяльність, який насамперед виявляється в конституційному визначенні обов'язків держави (статті $3,16,22$ ). Така відповідальність не зводиться лише до політичної чи моральної відповідальності публічної влади перед суспільством, а має певні ознаки юридичної відповідальності як застосування заходів публічно-правового (конституційно-правового або міжнародно-правового) характеру до держави та її органів за невиконання чи неналежне виконання своїх обов'язків.

Зокрема, стаття 55 Конституції України надає кожному право після використання всіх національних засобів правового захисту звертатися за захистом своїх прав і свобод до відповідних міжнародних судових установ чи відповідних органів міжнародних організацій, членом або учасником яких є Україна, а стаття 152 Конституції України зобов'язує державу відшкодовувати матеріальну чи моральну шкоду, завдану фізичним або юридичним особам актами і діями, які визнані неконституційними. Відшкодовується також державою завдана безпідставним осудженням шкода в разі скасування вироку суду як неправосудного (стаття 62 Конституції України) [2].

Огляд останніх досліджень і публікацій. Проблеми становлення України як соціальної держави були предметом уваги багатьох дослідників. В цьому контексті насамперед необхідно згадати дисертацію А.Ю. Бадиди «Соціальна держава в умовах глобалізації: теоретичні та порівняльно-правові аспекти», дисертацію I.В. Яковюка «Соціальна держава: питання теорії і шляхи ії становлення», монографію Н.М. Хоми «Моделі соціальної держави: світовий та український досвід», монографію О.В. Скрипнюк «Соціальна, правова держава в Україні: проблеми теоpiї і практики», дисертацію 0.З. Панкевич «Соціальна держава: поняття та загальнотеоретична характеристика» та інші.

() М. I. Даніліна, 2020 
Формулювання завдання дослідження. Метою статті є визначення конституційних засад становлення України як соціальної держави.

Виклад основного матеріалу. Актуальність проблеми посилення соціально-економічної ролі держави для сучасного демократичного суспільства зумовлена необхідністю виходу країни з внутрішньої соціальної кризи. Особливе загострення відбулося під впливом загальносвітових кризових процесів і переходу до стійкого економічного розвитку, який забезпечує побудову соціальної держави і громадянського суспільства. Питання щодо посилення соціальної ролі держави насамперед пов'язане з реалізацією соціальних та економічних прав та інтересів людини, роллю та місцем у соціально-економічному розвитку.

Передбачені законами соціально-економічні права не є абсолютними. Механізм реалізації цих прав може бути змінений державою, зокрема, через неможливість їх фінансового забезпечення шляхом пропорційного перерозподілу коштів з метою збереження балансу інтересів всього суспільства. Крім того, такі заходи можуть бути зумовлені необхідністю запобігання чи усунення реальних загроз економічній безпеці України, що згідно з частиною першою статті 17 Конституції України $€$ найважливішою функцією держави [3].

В. Шаповалов зазначає, що соціальна держава - це характеристика сучасної держави, за сенсом якої державна діяльність має бути спрямована на створення реальних стандартів матеріального добробуту, освіти, охорони здоров'я тощо і забезпечення таких стандартів для всіх громадян (індивідів), а також мінімізацію фактичної соціальної нерівності з її економічними наслідками та створення системи соціальної підтримки (захисту) тих, хто цього потребує. Поняття соціальної держави поєднується з відповідно трактованими ідеями соціальної справедливості та соціального захисту [4, с. 28$]$.

На думку О.С. Головащенко, соціальною є держава, яка активно реалізує широкомасштабну соціальну політику, сприяє здійсненню комплексу соціально-економічних, екологічних та культурних прав людини і громадянина в обсягах, що дозволяють втілити в життя конституційне визнання людини найвищою соціальною цінністю у суспільстві.

Слушною є думка О.С. Головащенко про те, що складність визначення чітких формальних меж категорії «достатній життєвий рівень» доводить, що орієнтація соціальної держави лише на забезпечення матеріального добробуту людей може призвести до обмеження її змісту виключно системою заходів із перерозподілу суспільного продукту [5, с. 18]. Насправді вона є більш змістовним явищем, а тому ефективна взаємодія соціальної держави і ринкової економіки в умовах правової держави можлива за умови, коли соціальна держава сприятиме формуванню відповідальної за забезпечення свого добробуту особи, для якої вона створює необхідні умови / можливості і вже в такому контексті бере на себе обов'язок піклуватися про забезпечення соціальної справедливості, добробуту своїх громадян, їх соціальний захист.

О.В. Бермічева аналізує поняття соціальної функції держави у широкому і вузькому значеннях. Так, соціальна функція в широкому значенні - це основний напрям діяльності держави, покликаний забезпечити соціальний захист, соціальне забезпечення, охорону здоров'я та нормальні умови життя для всього населення 
(насамперед для тих категорій громадян, які в силу різних обставин та об’єктивних умов не можуть повноцінно працювати), а також пов'язаний із виділенням необхідних коштів на освіту, відпочинок, будівництво доріг, житла, роботу транспорту і зв' язку тощо [6, с. 9].

Це визначення охоплює широке коло об’єктів впливу зазначеної функції. Воно має широкий зміст, включає в себе як соціальні права громадян (право на соціальне забезпечення, нормальні умови життя тощо), так і культурні (реалізація права на освіту тощо) та економічні права (реалізація права на відпочинок). О.В. Бермічева, роблячи наголос, що соціальна функція в вузькому значенні - це функція соціального захисту, функцію соціального захисту визначає як напрям діяльності держави, пов' язаний із соціальним забезпеченням громадян (формами соціального забезпечення є соціальне страхування, в тому числі і пенсійне, та соціальна допомога), а також забезпеченням достатнього життєвого рівня людині та членам їі сім'ї.

На думку I. Яковюка, соціальна держава має соціально-демократичну орієнтацію, специфіка якої полягає у функціональній єдності конституційних принципів демократичної, правової та соціальної державності [7, с. 99].

За Л. Четверіковою соціальна держава виконує такі завдання: досягнення загального добробуту суспільства шляхом надання мінімальної соціальної підтримки та створення сприятливих умов для самостійного досягнення високого рівня добробуту громадянами; забезпечення стабільності в суспільстві, екологічної безпеки [8, с. 105]. Така держава є правовою, має грунтовну законодавчу базу і розвинене громадянське суспільство, поєднує ринкову економіку за державним регулюванням.

Грунтуючись на змісті Конституції України, Г. Гетьман визначив соціальну державу як таку, що прагне і здатна здійснити політику, спрямовану на забезпечення громадянських прав для всіх членів суспільства, гарантування умов гідного життя людей, а також створення умов вільного і всебічного розвитку особистості та забезпечення реалізації втілених у законній формі інтересів кожного громадянина в поєднанні з інтересами всього суспільства [9, с. 2].

У запропонованих підходах йдеться про соціальну справедливість як елемент організації соціуму, а не взаємовідносин людей. Підставою для свободи як найвищої соціальної цінності людини насамперед є існуючі обов'язки держави стосовно індивіда, тобто держава повинна робити все, що сприяє його розвитку: видавати закони, відкривати відповідні установи і створювати всі сприятливі для цього умови, оскільки метою соціальної держави є турбота про людину, їі гідність, честь і свободу як громадянина й особистості [10, с. 40]. Практично всі названі вище визначення підкреслюють, що соціальною є держава, діяльність якої спрямована на забезпечення соціального захисту, соціальної справедливості, соціального добробуту, соціального співробітництва тощо. Виявом соціального характеру держави є державно-владна діяльність у соціальній сфері чи соціальна політика самої держави.

У загальному розумінні соціальною визнається така держава, яка прагне до забезпечення кожному громадянинові гідних умов існування, соціальної захищеності, співучасті в управлінні виробництвом, а в ідеалі приблизно однакових життевих шансів, можливостей для самореалізації особистості. 
Слід погодитися з П. Рабіновичем та Ю. Лободою, які вважають, що соціальна сутність держави характеризується двома складниками: загально-соціальним (здатність держави задовольняти потреби всього суспільства, насамперед забезпечувати його збереження, виживання як цілісного соціального «організму») та спеціально-соціального (можливість держави задовольняти інтереси насамперед домінуючої, зокрема панівної, частини населення) [11, с. 90].

Не менш важливе значення для формування соціальної держави в Україні має стаття 3 Основного Закону, яка проголосила людину, ї̈ життя і здоров’я, честь і гідність, недоторканність і безпеку найвищою соціальною цінністю в Україні; закріпила, що права і свободи людини та їх гарантії визначають зміст і спрямованість діяльності держави; встановила відповідальність держави перед людиною за свою діяльність, визнала головним обов'язком держави утвердження і забезпечення прав і свобод людини. Оскільки люди є найвищою соціальною цінністю, то держава, її органи та посадові особи зобов'язані створювати всі необхідні умови для найбільш повного та всебічного розкриття потенціалу кожного члена суспільства, забезпечення гідних умов життя кожної людини. Саме цю норму Конституції України безумовно можна вважати визначальною щодо формування в Україні реальних засад соціальної держави.

Ще один важливий аспект побудови соціальної держави закріплено у ст. 13 Конституції України, яка на найвищому правовому рівні визначила соціальну спрямованість економіки. Це означає, що всі відносини, які складаються в економічній сфері, мають враховувати необхідність створення ефективного механізму соціального захисту людини і громадянина, забезпечувати соціальну справедливість у суспільстві, що покладає на державу обов'язок на належному рівні виконувати свої соціальні функції.

Аналіз положень розділу II Конституції України дає всі підстави стверджувати, що на формування в Україні соціальної держави суттєвий вплив має закріплення на рівні Основного Закону України переліку прав та свобод людини і громадянина. До таких прав, зокрема, можна віднести: право на вільний розвиток особистості (ст. 23); рівність конституційних прав і свобод громадян, неможливість привілеїв чи обмежень за ознаками соціального походження та майнового стану (ст. 24); піклування і захист з боку держави своїх громадян, які перебувають за їі межами (ст. 25); права власності (ст. 41); право на підприємницьку діяльність (ст. 42); право на працю (ст. 43); право на відпочинок (ст. 44); право на соціальний захист (ст. 46); право на житло (ст. 47); право на достатній життєвий рівень (ст. 48); право на охорону здоров'я (ст. 49$)$.

Державу можна вважати соціальною, якщо в ній явно і на належному рівні визнані, закріплені та гарантовано забезпечені соціальна орієнтація економіки, політики, права; основні соціальні права і свободи людини; механізми соціальної солідарності та соціальної справедливості; гідний рівень життя та вільний розвиток людини; заходи щодо запобігання соціальній нерівності; заходи для «вирівнювання» соціальної нерівності, яка виникла; достатній рівень соціальної підтримки, допомоги та захисту людини; спеціальні заходи підтримки соціально незахищених верств суспільства. 
Висновки. Соціальна держава уособлює особливий, соціально орієнтований тип держави із розвинутою економікою, високим рівнем соціальної захищеності всіх громадян, а також затвердженням принципу соціальної справедливості. Соціальною є держава, яка активно реалізує широкомасштабну соціальну політику, сприяє здійсненню комплексу соціально-економічних, екологічних та культурних прав людини і громадянина в обсягах, що дозволяють втілити в життя конституційне визнання людини найвищою соціальною цінністю у суспільстві.

Основним напрямом подальшого конституційного розвитку в Україні слід вважати пошук оптимального балансу між «реалістичністю» у тлумаченні соціально-економічних прав людини (адже держава не повинна обіцяти більшого, ніж вона об'єктивно спроможна виконати) та імперативним конституційним визнанням людини та її гідності найвищою соціальною цінністю.

Конституційна інституціоналізація соціальної держави, яка включає в себе удосконалення системи правових гарантій забезпечення соціального захисту, соціальної безпеки та соціального розвитку людини і громадянина, стає одним з елементів конституційного ладу.

\section{Jimepamypa}

1. Конституція України : Закон України від 28.06.1996 № 254к/96-ВР. Відомості Верховної Ради України. 1996. № 30. Ст. 141.

2. Рішення Конституційного Суду України у справі за конституційним зверненням відкритого акціонерного товариства «Всеукраїнський Акціонерний Банк» щодо офіційного тлумачення положень пункту 22 частини першої статті 92 Конституції України, частин першої, третьої статті 2, частини першої статті 38 Кодексу України про адміністративні правопорушення (справа про відповідальність юридичних осіб) // Офіційний вісник України від 29.06.2001, № 24, сторінка 57, стаття 1076, код акта $19082 / 2001$.

3. Рішення Конституційного Суду України у справі за конституційними поданнями 49 народних депутатів України, 53 народних депутатів України і 56 народних депутатів України щодо відповідності Конституції України (конституційності) пункту 4 розділу VII «Прикінцеві положення» Закону України «Про Державний бюджет України на 2011 рік» / Офіційний вісник України від 20.01.2012, № 3, сторінка 55, стаття 100, код акта 59981/2012.

4. Шаповал В. «Соціалізація» як особливість сучасного конституційного регулювання / В. Шаповал // Вісник Конституційного Суду України. 2004. № 3. С. 28-48.

5. Головащенко О.С. Соціальна та правова держава: питання співвідношення : автореф. дис. ... канд. юрид. наук: 12.00 .01 / О.С. Головащенко; Нац. юрид. акад. України ім. Я.Мудрого. Х., 2008. $20 \mathrm{c}$.

6. Бермічева О.В. Соціальна функція держави в Україні : автореф. дис. канд. юрид. наук: 12.00.01 / О.В. Бермічева; Нац. ун-т внутр. справ. Х., 2002. 18 с.

7. Яковюк І.В. Соціальна і правова держава: співвідношення понять / І.В. Яковюк // Державне будівництво та місцеве самоврядування : зб. наук. пр. / Акад. правових наук України, Наук.-дослід. ін-т держ. будівництва та місцевого самоврядування. Х. : Право, 2001. Вип. 1. С. 99-105.

8. Четверікова Л.О. Соціальна держава: теоретичний аспект / Л.О. Четверікова // Укр. нац. ідея: реалії та перспективи розвитку : зб. наук. пр. Львів, 2004. Вип. 15. С. 103-107.

9. Тодыка Ю.Н. Основы конституционного строя Украины : моногр. / Ю.Н. Тодыка; Нац. юридич. акад. Украины им. Ярослава Мудрого, Акад. правовых наук Украины. Харьков : Факт, 2000. 176 с.

10. Скакун О.Ф. Теорія держави і права : підруч. / О.Ф. Скакун. Х. : Консум, 2009.520 с.

11. Рабінович П.М., Лобода Ю.П. Соціальна сутність держави як складник предмета теоретико-історичної юриспруденції / П.М. Рабінович, Ю.П. Лобода // Вісник Академії правових наук України. 1996. № 5. -С. 90-100. 


\section{Анотація}

Даніліна М. І. Конституційні основи становлення соціальної держави. - Стаття.

У статті на основі аналізу наукових поглядів вчених, норм чинного законодавства України досліджено та охарактеризовано конституційні засади становлення та формування України як соціальної держави. Визначено конституційне закріплення України соціальною державою, основи формування та побудови соціальної держави в розрізі Конституції України. Досліджено поняття соціальної функції держави. Визначено, які завдання виконує соціальна держава. 3'ясовано, що виявом соціального характеру держави є державно-владна діяльність у соціальній сфері чи соціальна політика самої держави.

Визначено, що соціальна сутність держави характеризується здатністю держави задовольняти потреби всього суспільства, насамперед забезпечувати його збереження, виживання як цілісного соціального «організму та можливість держави задовольняти інтереси насамперед домінуючої, зокрема панівної, частини населення. Досліджено, що важливе значення для формування соціальної держави в Україні має стаття 3 Основного Закону, яка проголосила людину, її життя і здоров’я, честь і гідність, недоторканність і безпеку найвищою соціальною цінністю в Україні; закріпила, що права і свободи людини та їх гарантії визначають зміст і спрямованість діяльності держави; встановила відповідальність держави перед людиною за свою діяльність; визнала головним обов'язком держави утвердження і забезпечення прав і свобод людини.

3'ясовано, що важливим аспектом конституційного закріплення України соціальною державою можна вважати статтю 8 Основного Закону України, яка гарантує всім суб’єктам суспільних відносин можливість звернення до суду для захисту конституційних прав і свобод людини і громадянина безпосередньо на підставі Конституції України. Ще один головний аспект побудови соціальної держави закріплено у статті 13 Конституції України, яка на найвищому правовому рівні визначила соціальну спрямованість економіки. Розділ II Конституції України дає всі підстави стверджувати, що на формування в Україні соціальної держави суттєвий вплив має закріплення на рівні Основного Закону України переліку прав та свобод людини і громадянина.

Ключові слова: Конституція України, конституційний лад, соціальна держава, соціальні права, соціальна політика, соціальний захист, права та свободи людини і громадянина.

\section{Summary}

Danilina M. I. Constitutional bases of formation of the social state. - Article.

In the article on the basis of the analysis of scientific views of scientists, norms of the current legislation of Ukraine the constitutional bases of formation and formation of Ukraine as the social state are investigated and characterized. The article investigates the constitutional principles of formation of Ukraine as a social state, aspects of constitutional securing of Ukraine as a social state, aspects of building a social state in the context of the Constitution of Ukraine. The constitutional consolidation of Ukraine by the welfare state is determined. Fundamentals of formation and construction of the welfare state in the context of the Constitution of Ukraine.

The concept of social function of the state is investigated. It is determined what tasks the welfare state performs. Manifestation of the social nature of the state is the state-authoritative activity in the social sphere, or in other words - the social policy of the state itself. The social essence of the state is characterized by the ability of the state to meet the needs of society, especially to ensure its preservation, survival as a whole social "organism" and the ability of the state to meet the interests of the dominant, in particular dominant, part of the population.

Researched that Article 3 of the Basic Law, which proclaimed a person, his life and health, honor and dignity, inviolability and security, is the highest social value in Ukraine, is important for the formation of the welfare state in Ukraine; established that human rights and freedoms and their guarantees determine the content and direction of the state; established the responsibility of the state to the person for the activity; recognized the main duty of the state to establish and ensure human rights and freedoms. An important aspect of the constitutional consolidation of Ukraine by the welfare state is Article 8 of the Basic Law of Ukraine, which guarantees all subjects of public relations the opportunity to go to court to protect the constitutional rights and freedoms of man and citizen directly on the basis of the Constitution of Ukraine. Another main aspect of building a welfare state is enshrined in Article 13 of the Constitution of Ukraine, which at the highest legal level has determined the social orientation of the economy. Section II of the Constitution of Ukraine gives all grounds to assert that the establishment of a broad list of human and civil rights and freedoms at the level of the Basic Law of Ukraine has a significant impact on the formation of the welfare state in Ukraine.

Key words: The Constitution of Ukraine, constitutional system, social state, social rights, social policy, social protection, human and civil rights and freedoms. 